\title{
Analisis Sistem Pengelolaan Barang Milik Daerah Pada Pemerintah Kabupaten Gorontalo
}

\author{
RUKIAH RAHMAN ALI ${ }^{1}$, HERMAN KARAMOY ${ }^{2}$, JESSY D.L WARONGAN ${ }^{3}$
}

\author{
${ }^{1,2,3}$ Program Magister Akuntansi, Fakultas Ekonomi dan Bisnis Universitas Sam Ratulangi \\ email : $\underline{\text { rukiahrahmana@gmail.com }}{ }^{1}$, hkaramoy@yahoo.com ${ }^{2}$, jdimarcus@gmail.com $^{3}$
}

\begin{abstract}
Management of the local Asset must be implemented properly in order to give an idea of the richness of the area, and can be used for basic financial statements. This study aims at analyzing the management system of Regional Property at Gorontalo District Government. This is a qualitative research study with a case study approach. The data were obtained through in-depth interview, observation and document analysis. The semistructured and in-depth interviews were conducted for 45 to 60 minutes. The triangulation method was used to test the validity or credibility of the data and data sources. The interviews were transcribed and were analyzed by coding or giving themes and making a conceptualization with scientific statements. Then, the results of the interpretation were summarized in the narrative text. The result of the research shows that there are some obstacles in the management of Regional Property in Gorontalo Regency Government. The absence of regulation is in the form of local regulations and SOP. Lack of knowledge and understanding of how to use the property and of $R P$, the planning for required property needs is constrained by the limited budget so that the required property cannot be obtained, the issue of security and maintenance is emerged from the absence of representative warehouses for property storage, evidence of ownership in the form of certificates that are still on behalf of the Ministry, removal is constrained by the unknown of the inexistence of property.
\end{abstract}

Keywords: RP Management, RP Regulation, RP Problems.

\begin{abstract}
Abstrak. Pengelolaan Barang Milik Daerah harus dilaksanakan dengan baik agar dapat memberikan gambaran tentang kekayaan daerah, serta dapat digunakan untuk dasar penyusunan laporan keuangan. Penelitian ini bertujuan menganalisis sistem Pengelolaan Barang Milik Daerah pada Pemerintah Kabupaten Gorontalo. Metode penelitian menggunakan kualitatif dengan pendekatan studi kasus. Data diperoleh melalui teknik wawancara mendalam, pengamatan dan studi dokumentasi. Wawancara menggunakan In-depth interview jenis semi terstruktur dilakukan selama 45 hingga 60 menit. Metode triangulasi digunakan dalam pengujian validitas atau kredibilitas data dan sumber data. Data transkrip yang diuraikan dari hasil wawancara dianalisis dengan metode analisis kemudian diberi tema/ coding dan dilakukan konseptualisasi pernyataan ilmiah. Hasil interpretasi disimpulkan dalam teks naratif. Hasil penelitian menunjukkan terdapat beberapa kendala dalam pengelolaan Barang Milik Daerah di Pemerintah Kabupaten Gorontalo. Belum adanya regulasi berupa Perda dan SOP, minimnya pengetahuan dan pemahaman Pengguna Barang tentang pengelolaan BMD, perencanaan kebutuhan barang terkendala kondisi anggaran yang terbatas sehingga ada kebutuhan yang seharusnya diadakan tapi belum bisa direalisasikan, pengamanan dan pemeliharaan terkendala belum adanya gudang yang representatif untuk penyimpanan barang, bukti kepemilikan berupa sertifikat yang masih atas nama Kementerian, penghapusan terkendala adanya barang yang sudah tidak diketahui lagi keberadaannya.
\end{abstract}

Kata Kunci: Pengelolaan BMD, Regulasi BMD, Masalah BMD.

\section{Pendahuluan}

Barang Milik Daerah sebagai salah satu unsur penting dalam rangka penyelenggaraan pemerintahan, pembangunan, pemberdayaan dan pelayanan kepada masyarakat harus dikelola dengan baik dan benar dengan memperhatikan asas fungsional, kepastian hukum, transparansi, efisiensi, akuntabilitas dan kepastian nilai. Untuk menunjang pengelolaan Barang Milik Daerah agar terlaksana dengan baik dan benar maka diperlukan adanya kesamaan persepsi dan langkah secara integral dan menyeluruh dari unsur-unsur yang terkait dalam pengelolaan Barang Milik Daerah. Untuk itu Pemerintah mengeluarkan dan mengesahkan Peraturan Menteri Dalam Negeri Nomor 19 Tahun 2016 Tentang Pengelolaan Barang Milik Daerah, dimana sebelumnya mengeluarkan Peraturan Pemerintah Nomor 27 Tahun 2014 Tentang Pengelolaan Barang Milik Negara/Daerah, dan menyempurnakannya serta keputusan terkait lainnya di bidang pengelolaan Barang Milik Daerah.

Berdasarkan Laporan Hasil Pemeriksaan BPK pada tahun 2011 s/d tahun 2015 menunjukkan bahwa pengelolaan Barang Milik Daerah yang semakin berkembang dan kompleks belum dapat dilaksanakan Pemerintah Kabupaten Gorontalo secara optimal karena masih terdapat beberapa 
permasalahan diantaranya yaitu inventarisasi Barang Milik Daerah yang tidak tepat karena belum memiliki data barang yang valid. Ada barang yang tidak dicatat, barang yang tidak ada justru masih dicatat dan barang yang dicatat tapi tidak didukung dengan dokumen kepemilikan yang sah. Kemudian tidak tersedianya ruang penyimpanan barang yang representatif mengakibatkan barang yang mudah berpindah tangan seperti laptop, kamera, proyektor LCD dan lainnya mudah hilang, rusak atau dicuri. Masalah lainnya lagi yaitu pengelolaan Barang Milik Daerah di SKPD belum didukung sumber daya manusia yang kompeten, beberapa diantara Pengurus Barang SKPD belum optimal penguasaannya dalam mengoperasikan komputer dan belum mengerti penatausahaan Barang Milik Daerah.

Penelitian menyangkut Barang Milik Daerah juga dilakukan oleh Hasfi (2013) dan Sumampow (2015). Hasfi (2013) melakukan penelitian tentang Pengelolaan Barang Milik Daerah. Penelitian ini bertujuan untuk mengetahui dan mendeskripsikan proses pengelolaan Barang Milik Daerah oleh Dinas Pendapatan, Pengelolaan Keuangan dan Aset (DPPKA) Kabupaten Sintang serta faktor-faktor yang mempengaruhinya. Hasil penelitian menunjukkan bahwa, pengelolaan Barang Milik Daerah pada DPPKA Kabupaten Sintang belum sepenuhnya terlaksana dengan baik. Hal ini meliputi aspek perencanaan kebutuhan dan penganggaran, pengadaan, penerimaan dan penyaluran, penggunaan, penatausahaan, pengamanan dan pemeliharaan, pemanfaatan, penilaian dan penghapusan Barang Milik Daerah yang kurang sesuai dengan kebutuhan organisasi, sehingga menimbulkan inefisiensi dan kemubaziran.

Sumampow (2015) melakukan penelitian tentang Implementasi Kebijakan Pengelolaan Barang Milik Daerah pada Dinas Pendidikan, Pemuda dan Olahraga Kabupaten Sigi. Penelitian ini bertujuan untuk mengetahui sejauh mana pelaksanaan implementasi kebijakan pengelolaan Barang Milik Daerah di Dinas Pendidikan, Pemuda dan Olahraga Kabupaten Sigi. Hasil penelitian menunjukkan bahwa implementasi kebijakan pengelolaan Barang Milik Daerah pada Dinas Pendidikan, Pemuda dan Olahraga Kabupaten Sigi belum berjalan dengan baik. Hal ini karena 4 (empat) aspek yang diteliti, menjelaskan bahwa pada aspek komunikasi dimana kurangnya sosialisasi dilaksanakan, pada aspek sumber daya utamanya sumber daya manusia dan sumber daya anggaran kurang memadai, dan pada aspek disposisi dapat terlihat dengan kurangnya tanggung jawab aparat pengelola Barang Milik Daerah serta pada aspek struktur birokrasi dimana belum adanya SOP pengelolaan Barang Milik Daerah yang dibuat. Tujuan yang ingin dicapai dalam penelitian ini adalah untuk menganalisis kesesuaian sistem pengelolaan Barang Milik Daerah dengan Peraturan Menteri Dalam Negeri Nomor 19 Tahun 2016, apa hambatan dan apa upaya yang dilakukan guna memperbaiki sistem pengelolaan Barang Milik Daerah pada Pemerintah Kabupaten Gorontalo.

\section{Model Analisis}

Model analisis pada penelitian ini dimulai dengan telaah paradigma melalui kajian isu-isu empirik tentang ruang lingkup pengelolaan Barang Milik Daerah yang merujuk pada Peraturan Menteri Dalam Negeri Nomor 19 Tahun 2016, langkah berikut adalah fokus penelitian tentang Analisis Sistem/Proses Pengelolaan Barang Milik Daerah dan didukung dengan studi kepustakaan serta tahapan survey awal yang diperoleh dari Bidang Aset Badan Keuangan, Pengguna Barang SKPD dan Pengurus Barang. Selanjutnya adalah tahapan pengumpulan data berupa data interview, data observasi dan data dokumentasi. Selanjutnya dilakukan analisis data, memeriksa keabsahan data dan menyusun laporan penelitian.

\section{Metode Penelitian}

Penelitian ini menggunakan metode kualitatif studi kasus (case study research). Menurut Yin (2014:1) penulisan studi kasus adalah sebuah metode penulisan yang secara khusus menyelidiki fenomena kontemporer yang tedapat dalam konteks kehidupan nyata, bilamana batas-batas antara fenomena dan konteks tidak nampak secara tegas atau jelas dan menggunakan berbagai sumber atau multi sumber bukti. Adapun tujuan dari penulisan studi kasus yakni untuk menjawab pertanyaan "how atau why" terhadap sesuatu yang diteliti. Teknik pengumpulan data yang digunakan dalam penelitian ini adalah melalui pengamatan/observasi(observation), wawancara mendalam (indepth interviews), dan dokumentasi (documentation). Selanjutnya, uji keabsahan data dalam penelitian kualitatif meliputi uji credibility (validitas internal), transferability (validitas eksternal), dependability (reliabilitas) dan confirmability (objektivitas). Yin (2014) menyatakan bahwa ada enam sumber bukti yang dapat dijadikan fokus bagi pengumpulan data studi kasus dilakukan dengan studi dokumen, rekaman arsip, wawancara, observasi langsung, observasi pemeran serta dan perangkat fisik. 


\section{Analisis dan Pembahasan}

Penelitian dilakukan selama \pm 2 (dua) bulan sejak bulan Mei 2017 hingga bulan Juni 2017, wawancara dilakukan sesuai dengan pedoman wawancara kepada informan kunci yang sudah ditentukan menggunakan alat perekam untuk merekam seluruh isi wawancara, serta menggunakan instrumen pendukung antara lain buku catatan,alat perekam berupa audio/video, kamera untuk mendokumentasikan kegiatan dilapangan dan laptop untuk mengetik hasil penelitian dan rekaman sehingga berbentuk transkrip wawancara.

\section{Kesesuaian Sistem Pengelolaan Barang Milik Daerah Dengan Peraturan Menteri Dalam Negeri Nomor 19 Tahun 2016}

Sebagai salah satu unsur penting dalam penyelenggaraan pemerintahan dan pelayanan kepada masyarakat, sangat penting bagi SKPD untuk mengelola Barang Milik Daerah dengan sebaik mungkin. Untuk menunjang pengelolaan Barang Milik Daerah agar menjadi lebih baik, sejak tahun 2011 Pemerintah Kabupaten Gorontalo sudah mulai menggunakan Sistem Informasi Barang Milik Daerah (SIMDA BMD) dalam penatausahaan aset tetap, untuk menyajikan data keuangan dan data fisik atas Barang Milik Daerah yang dicatat dan dilaporkan dalam neraca aset.

\section{Pejabat Pengelola Barang Milik Daerah}

Pejabat Pengelola Barang Milik Daerah pada Pemerintah Kabupaten Gorontalo terdiri dari Bupati selaku Pemegang Kekuasaan pengelolaan Barang Milik Daerah, Sekretaris Daerah selaku Pengelola Barang, Badan Keuangan dalam hal ini Bidang Aset selaku Pembantu Pengelola Barang, Kepala SKPD selaku Pengguna Barang dan Pengurus Barang. Berdasarkan hasil wawancara dapat disimpulkan bahwa para Pejabat Pengelola Barang Milik Daerah pada Pemerintah Kabupaten Gorontalo sudah sesuai dengan peraturan. Namun masih terdapat permasalahan yaitu Pemerintah Kabupaten Gorontalo masih mengalami keterbatasan SDM karena tidak adanya Penyimpan Barang pada setiap SKPD. Dengan merangkapnya tugas Pengurus Barang sekaligus sebagai Penyimpan Barang menyebabkan Pengurus Barang kurang optimal dalam mengurus barang yang jumlahnya banyak dan ini tidak sesuai dengan peraturan terkait tugas pokok dan fungsi Pengurus Barang dan Penyimpan Barang yang terpisah. Masalah lainnya lagi terkait Pengurus Barang yang masa jabatannya belum cukup 1 (satu) tahun tapi sudah diganti, sehingga butuh penyesuaian lagi terhadap Pengurus Barang pengganti. Kemudian ada beberapa diantara Pengurus Barang yang belum optimal mengoperasikan komputer dalam melakukan penginputan data pada SIMDA BMD.

Untuk itu upaya yang dilakukan Pemerintah Kabupaten Gorontalo dalam meningkatkan kompetensi SDM khususnya terhadap Pejabat Pengelola yaitu pada tahun 2014 seluruh Pengurus Barang mulai dari Badan, Dinas, Kantor sampai dengan Kecamatan sudah mengikuti Diklat tentang Penatausahaan Barang Milik Daerah kerjasama dengan Universitas Patria Artha di Makassar. Selain itu ada juga Bimtek tentang pengelolaan Barang Milik Daerah yang diselenggarakan setiap tahun. Untuk mendukung tugas pokok dan fungsinya dalam mengelola Barang Milik Daerah, para Pejabat Pengelola dituntut untuk memiliki kompetensi yang dapat diukur berdasarkan latar belakang pendidikan, pengalaman dan pelatihan teknis/Diklat yang diikuti sesuai jabatannya dan juga pemahaman terkait tugas pokok dan fungsinya sebagai Pejabat Pengelola Barang Milik Daerah.

\section{Perencanaan Kebutuhan Barang Milik Daerah}

Perencanaan kebutuhan Barang Milik Daerah pada Pemerintah Kabupaten Gorontalo berpedoman pada Rencana Kerja yang melibatkan Pengguna Barang, yang dilakukan mulai dari tahapan penyusunan Rencana Kebutuhan Barang Milik Daerah (RKBMD) dan Rencana Kebutuhan Pemeliharaan Barang Milik Daerah (RKPBMD), berdasarkan usulan Bidang/Bagian di SKPD masingmasing dengan memperhatikan kebutuhan pelaksanaan tugas dan fungsi SKPD serta ketersediaan Barang Milik Daerah yang ada dan disampaikan kepada Bupati melalui Sekda dan Badan Keuangan paling lambat pertengahan bulan januari 1 (satu) tahun sebelum rencana kebutuhan barang untuk tahun dimaksud. Setelah usulan tersebut disetujui untuk selanjutnya dimasukkan kedalam Rencana Kebutuhan Anggaran (RKA) pada SKPD. Berdasarkan hasil wawancara dapat disimpulkan bahwa pelaksanaan proses perencanaan kebutuhan dan penganggaran pada Pemerintah Kabupaten Gorontalo secara umum sudah dilaksanakan sesuai dengan peraturan. Namun hasil penelitian menunjukkan bahwa pelaksanaan proses perencanaan kebutuhan Barang Milik Daerah pada Pemerintah Kabupaten Gorontalo masih belum optimal. Terkadang ada kebutuhan barang SKPD yang seharusnya diadakan 
tapi karena kondisi anggaran yang tidak memungkinkan sehingga kebutuhan barang tersebut belum bisa direalisasikan. Dengan kondisi seperti ini maka SKPD berupaya untuk memanfaatkan semaksimal mungkin aset yang tersedia.

Masalah lainnya lagi yaitu terkadang SKPD dalam merencanakan kebutuhan barang tidak sesuai kebutuhan atau sering berlebihan. Dimana dalam perencanaan kebutuhan Barang Milik Daerah, seharusnya SKPD memformulasikan rencana kebutuhan barang dari barang-barang apa saja yang dibutuhkan untuk mendukung tugas dan fungsi SKPD dikurangi dengan barang-barang apa saja yang telah tersedia dan siap digunakan berdasarkan informasi jumlah, keberadaan, kondisi dan status penggunaan Barang Milik Daerah. Kekurangan antara kebutuhan dan ketersediaan barang inilah yang akan ditetapkan oleh Bidang Aset melalui SKPD untuk dianggarkan dalam RKA SKPD. Perencanaan yang benar dapat menghasilkan anggaran yang tepat dan tidak berlebih. Penerapan kebijakan pengelolaan Barang Milik Daerah memerlukan kerjasama antara pihak-pihak yang terkait dengan pengelolaan Barang Milik Daerah. Oleh karena itu, dibutuhkan komunikasi yang baik antara pihakpihak tersebut. Komunikasi dalam organisasi merupakan suatu proses yang amat kompleks dan rumit (Edwards III, 1980 dalam Juanda, 2011). Agar implementasi berjalan efektif, siapa yang bertanggung jawab melaksanakan sebuah keputusan harus mengetahui apakah mereka dapat melakukannya. Sesungguhnya implementasi kebijakan harus diterima oleh semua personil dan harus mengerti secara jelas dan akurat mengenai maksud dan tujuan kebijakan. Tidak cukupnya komunikasi kepada para implementor secara serius mempengaruhi implementasi kebijakan.

Hal ini didukung juga dengan salah satu fungsi proses logistik menurut Subagya (1996:10) yaitu fungsi perencanaan dan penentuan kebutuhan yang mencakup aktivitas dalam menetapkan sasaransasaran, pedoman-pedoman, pengukuran penyelenggaraan bidang logistik. Sementara penentuan kebutuhan merupakan perincian dari fungsi perencanaan, bilamana perlu semua faktor yang mempengaruhi penentuan kebutuhan harus diperhitungkan. Setiap tahap dan langkah kegiatan pengadaan logistik tersebut harus mendapat perhatian secara proposional guna mendukung kinerja setiap unit kerja maupun mendukung efektivitas dan efisiensi organisasi secara keseluruhan.

\section{Pengadaan}

Pengadaan pada Pemerintah Kabupaten Gorontalo mengacu pada Peraturan Presiden Nomor 54 Tahun 2010 Tentang Pengadaan Barang/Jasa Pemerintah dan dilaksanakan oleh panitia pengadaan di tiap-tiap SKPD atau biasa disebut Kelompok Kerja (POKJA) dan melalui Unit Layanan Pengadaan (ULP) dengan menggunakan Layanan Pengadaan Barang Dan Jasa Secara Elektronik (LPSE). Panitia pengadaan ditetapkan dengan Surat Keputusan Bupati dengan mengikuti mekanisme yang ditetapkan dalam aturan pengadaan. Setelah melalui proses pada panitia pengadaan SKPD atau tahapan di ULP, selanjutnya dokumen administrasi pengadaan sebagai bukti pertanggungjawaban dilaporkan ke Bidang Aset untuk proses verifikasi pengadaan guna menyamakan akun atau kode rekening barang dan jasa. Hal ini dimaksudkan untuk memastikan bahwa seluruh tahapan dan syarat-syarat dalam pengadaan barang telah dipenuhi oleh SKPD/ULP dan pihak penyedia barang. Berdasarkan hasil wawancara dapat disimpulkan bahwa pelaksanaan proses pengadaan pada Pemerintah Kabupaten Gorontalo secara umum sudah dilaksanakan sesuai dengan peraturan, karena sudah dilakukan oleh panitia pengadaan barang/jasa melalui ULP. Dimana proses pengadaan Barang Milik Daerah harus mengikuti hukum yang berlaku secara khusus untuk pengadaan barang. Akuntabilitas hukum (Mardiasmo, 2000 dalam Hasfi, 2013) terkait dengan jaminan adanya kepatuhan terhadap hukum dan peraturan lain yang disyaratkan dalam penggunaan kekayaan publik.

\section{Penggunaan}

Penggunaan pada Pemerintah Kabupaten Gorontalo dilakukan dengan mengajukan usulan permohonan penetapan status penggunaan oleh Pengguna Barang kepada Pengelola Barang melalui Bidang Aset, dan melampirkan semua dokumen yang menjadi dasar perolehan Barang Milik Daerah. Kemudian Bidang Aset akan meneliti usul penggunaan barang yang diterima dari SKPD untuk ditetapkan status penggunaannya. Setelah disetujui maka akan diterbitkan Surat Persetujuan atau Surat Keputusan. Penetapan status penggunaan Barang Milik Daerah juga disesuaikan dengan tugas pokok dan fungsi SKPD. Berdasarkan hasil wawancara dapat disimpulkan bahwa pelaksanaan proses penetapan status penggunaan pada Pemerintah Kabupaten Gorontalo sudah dilaksanakan sesuai dengan peraturan. Dimana dalam Peraturan Menteri Dalam Negeri Nomor 19 Tahun 2016 dijelaskan bahwa Barang Milik Daerah ditetapkan status penggunaannya oleh Bupati untuk penyelenggaraan 
tugas dan fungsi SKPD, dan dapat dioperasikan oleh pihak lain dalam rangka mendukung pelayanan umum sesuai tugas pokok dan fungsi SKPD yang bersangkutan. Menurut Edward III (1980) dalam Sumampow (2015) bahwa disposisi atau sikap mempengaruhi efektivitas implementasi kebijakan. Jika implementor setuju dengan bagian-bagian isi dari kebijakan maka mereka akan melaksanakan dengan senang hati tetapi jika pandangan mereka berbeda dengan pembuat kebijakan maka proses implementasi akan mengalami banyak masalah. Dukungan para pejabat pelaksana sangat dibutuhkan dalam mencapai sasaran program. Dukungan dari pimpinan sangat mempengaruhi pelaksanaan program hingga dapat mencapai tujuan secara efektif dan efisien.

\section{Pemanfaatan}

Pemanfaatan pada Pemerintah Kabupaten Gorontalo yang dilaksanakan berupa sewa dan pinjam pakai. Seperti BPU Kecamatan Telaga yang disewa oleh pihak BRI Unit Telaga, Pabrik Tepung Kelapa yang disewa oleh PT. Trijaya Tangguh dan Agung Supermarket yang tadinya adalah Gedung Perkantoran. Sewa dilakukan atas persetujuan Bupati selaku Penguasa Barang dengan terlebih dahulu membuat Surat Perjanjian sesuai prosedur dan ketentuan yang berlaku. Untuk bentuk pemanfaatan berupa Bangun Guna Serah (BGS) dan Bangun Serah Guna (BSG) belum pernah dilakukan. Berdasarkan hasil wawancara dapat disimpulkan bahwa pelaksanaan proses pemanfaatan pada Pemerintah Kabupaten Gorontalo secara umum sudah dilaksanakan sesuai dengan peraturan. Dimana bentuk pemanfaatan Barang Milik Daerah dalam Peraturan Menteri Dalam Negeri Nomor 19 Tahun 2016 antara lain berupa sewa, pinjam pakai, KSP, BGS atau BSG dan KSPI. Hal ini terkait juga dengan penelitian Juanda (2011) yang menyatakan bahwa dalam usaha optimalisasi pemanfaatan aset dapat dilakukaFn melalui perantara investasi guna memasarkan aset-aset pemerintah daerah yang potensial dan kerjasama dengan investor, membuat dan memadukan dalam MOI (Memorandum Of Investment) antara pemerintah daerah dan investor, serta memberikan jasa konsultasi kepada pemerintah daerah atas kerjasama dengan investor tersebut, sehingga tidak akan membebani anggaran belanja daerah khususnya biaya pemeliharaan dan kemungkinan penyerobotan pihak ketiga dan bahkan mampu menghasilkan pendapatan asli daerah.

\section{Pengamanan dan Pemeliharaan}

Pengamanan pada Pemerintah Kabupaten Gorontalo yang dilaksanakan terkait pengamanan fisik yaitu dengan melakukan kodefikasi atau pelabelan terhadap seluruh barang, dan pada Tahun 2017 akan dilakukan pematokan tanda batas atau tanda pemegang tanah milik Pemerintah Kabupaten Gorontalo. Untuk pengamanan administratif dilakukan dengan dibuatkannya SK untuk masing-masing Pemegang Barang kemudian untuk surat-surat berharga seperti sertifikat kepemilikan tanah dan BPKB Kenderaan Dinas disimpan kedalam brankas di Bidang Aset. Untuk pengamanan hukum dilakukan terhadap tanah dan bangunan milik Pemerintah Daerah dengan mendaftarkan pensertifikatan sekitar 200 (dua ratus) bidang tanah dan bangunan milik Pemerintah Daerah melalui BPN. Berdasarkan hasil wawancara dapat disimpulkan bahwa pelaksanaan proses pengamanan pada Pemerintah Kabupaten Gorontalo secara umum sudah dilaksanakan sesuai dengan peraturan. Dimana dalam Peraturan Menteri Dalam Negeri Nomor 19 Tahun 2016 dijelaskan bahwa Pengelola Barang, Pengguna Barang dan/atau Kuasa Pengguna Barang wajib melakukan pengamanan Barang Milik Daerah yang berada dalam penguasaannya. Pengamanan tersebut meliputi pengamanan fisik, pengamanan administratif dan pengamanan hukum. Dalam rangka pengamanan administratif dibutuhkan sistem penatausahaan yang dapat menciptakan pengendalian (controlling) atas Barang Milik Daerah.

Namun hasil penelitian menunjukkan bahwa pelaksanaan proses pengamanan pada Pemerintah Kabupaten Gorontalo belum optimal karena masih terdapat permasalahan. Terkait dengan pengamanan fisik yaitu hilangnya barang yang mudah berpindah tangan seperti Laptop, Kamera, Proyektor dan LCD serta ada juga barang-barang yang tidak diketahui keberadaannya, hal ini karena tidak tersedianya gudang penyimpanan barang yang representatif di tiap SKPD. Terkait dengan pengamanan hukum yaitu terdapat beberapa bidang tanah dan bangunan milik Pemerintah Kabupaten Gorontalo yang belum memiliki sertifikat atau bukti kepemilikan yang sah dan ada juga sertifikat kepemilikan yang masih atas nama Kementerian, hal ini karena sebelumnya Pemerintah Kabupaten Gorontalo masih tergabung dengan Pemerintah Provinsi Sulawesi Utara. Untuk itu upaya yang dilakukan Pemerintah Kabupaten Gorontalo terkait pengamanan administratif yaitu dibuatkan SK bagi setiap masing-masing Pemegang Barang di SKPD, kemudian untuk setiap Pengguna Barang dibuatkan Surat Perjanjian yang isi dari perjanjian tersebut adalah apabila mengalami mutasi Dinas atau tiba masa pensiun, maka 7 (tujuh) hari setelahnya wajib mengembalikan Barang Milik Daerah yang 
diganakannya. Terkait pengamanan fisik yaitu dengan melakukan kodefikasi atau pelabelan terhadap seluruh Barang Milik Daerah. Terkait pengamanan hukum yaitu terhadap sertifikat kepemilikan tanah dan bangunan milik Pemerintah Daerah yang masih atas nama Kementerian atau perorangan, Bidang Aset dalam hal ini Badan Keuangan selaku Pembantu Pengelola Barang sudah melakukan penelusuran atas bukti-bukti kepemilikan tanah kemudian melakukan konsultasi maupun konsolidasi dan mendaftarkannya ke pihak Badan Pertanahan Nasional (BPN) untuk proses balik nama. Meskipun sudah memiliki bukti Surat Serah Terima Hibah sebagai bentuk penguasaan barang, namun berdasarkan Standar Akuntansi Pemerintah (SAP) bahwa kepemilikan Aset itu akan lebih handal jika disertai dengan bukti kepemilikan Aset tersebut.

Suwanda (2013:296) mendefinisikan pemeliharaan adalah kegiatan atau tindakan yang dilakukan agar semua Barang Milik Daerah selalu dalam keadaan baik dan siap untuk digunakan secara berdaya guna dan berhasil guna. Pemeliharaan berpedoman pada daftar kebutuhan pemeliharaan barang dan biaya pemeliharaan Barang Milik Daerah dibebankan pada Anggaran Pendapatan dan Belanja Daerah kecuali dalam hal Barang Milik Daerah dilakukan pemanfaatan dengan pihak lain. (Simamora, 2013). Pemeliharaan pada Pemerintah Kabupaten Gorontalo yang dilaksanakan mengacu di DPA pada SKPD masing-masing. Untuk proses kapitalisasi terhadap aset pencatatannya berdasarkan harga perolehan sebagai pelaksanaan dari kebijakan akuntansi terkait kapitalisasi Barang Milik Daerah. Namun hasil penelitian menunjukkan bahwa pelaksanaan proses pemeliharaan pada Pemerintah Kabupaten Gorontalo belum optimal karena diakibatkan kelalaian para Pengurus Barang di SKPD yang tidak melakukan pencatatan barang yang dipelihara kedalam Kartu Pemeliharaan. Hal ini menggambarkan ketidakpatuhan para Pejabat Pengelola Barang terutama Pengurus Barang terhadap Peraturan Perundang-undangan. Menurut Taylor (2006:266) kepatuhan adalah memenuhi permintaan orang lain, didefinisikan sebagai suatu tindakan atau perbuatan yang dilakukan berdasarkan keinginan orang lain atau melakukan apa-apa yang diminta oleh orang lain, kepatuhan mengacu pada perilaku yang terjadi sebagai respons terhadap permintaan langsung dan berasal dari pihak lain. Dalam rangka tertib pemeliharaan setiap jenis Barang Milik Daerah, masingmasing Pengurus Barang harus melakukan pencatatan kedalam kartu pemeliharaan/perawatan.

\section{Penilaian}

Penilaian pada Pemerintah Kabupaten Gorontalo mengacu pada mekanisme penilaian yang diatur dalam PMK Penilaian dan berdasarkan Standar Akuntansi Pemerintahan (SAP). Pemerintah Kabupaten Gorontalo menetapkan personil dan melakukan kerjasama dengan Penilai Pemerintah yakni pihak Kantor Pelayanan Kekayaan Negara dan Lelang (KPKNL) untuk melakukan penilaian terhadap Aset daerah terutama terhadap tanah yang belum memiliki nilai atau bangunan yang sudah tercatat tapi belum diberi nilai, berdasarkan nilai NJOP tanah yang berlaku pada saat sekarang. Berdasarkan hasil wawancara dapat disimpulkan bahwa pelaksanaan proses penilaian pada Pemerintah Kabupaten Gorontalo sudah dilaksanakan sesuai dengan peraturan. Dimana dalam Peraturan Menteri Dalam Negeri Nomor 19 Tahun 2016 dijelaskan bahwa penilaian Barang Milik Daerah dilakukan dalam rangka penyusunan neraca pemerintah daerah, pemanfaatan, atau pemindahtanganan dengan berpedoman pada Standar Akuntansi Pemerintahan (SAP). Penilaian Barang Milik Daerah dilakukan oleh Penilai Pemerintah atau Penilai Publik yang ditetapkan oleh Gubernur/Bupati/Walikota. Hal ini didukung juga oleh Mardiasmo (2009) yang menyebutkan bahwa akuntabilitas publik adalah kewajiban pihak pemegang amanah untuk memberikan pertanggungjawaban, menyajikan, melaporkan, dan mengungkapkan segala aktivitas dan kegiatan yang menjadi tanggung jawabnya kepada pihak pemberi amanah (principal) yang memiliki hak dan kewenangan untuk meminta pertanggungjawaban tersebut.

\section{Pemindahtanganan}

Pemindahtanganan pada Pemerintah Kabupaten Gorontalo yang dilakukan baru berupa penjualan. Tahapan dilakukan sesuai dengan peraturan yang diawali dengan penilaian oleh KPKNL untuk menetapkan nilai wajar sampai dengan proses lelang. Berdasarkan hasil wawancara dapat disimpulkan bahwa pelaksanaan proses pemindahtanganan pada Pemerintah Kabupaten Gorontalo secara umum sudah dilaksanakan sesuai dengan peraturan. Dimana dalam Peraturan Menteri Dalam Negeri Nomor 19 Tahun 2016 dijelaskan bahwa dalam rangka pemindahtanganan Barang Milik Darah maka dilakukan penilaian untuk mendapatkan nilai wajar. Chabib Sholeh dan Heru Rochmansjah (2010) serta Darise (2009) menyebutkan bahwa pemindahtanganan Barang Milik Daerah berdasarkan asas kepastian nilai yaitu adanya ketepatan jumlah dan nilai barang yang akan dilakukan 
pemindahtanganan. Direktorat Jenderal Perimbangan Keuangan (2014) menyatakan bentuk-bentuk pemindahtanganan terdiri dari penjualan, tukar menukar, hibah dan penyertaan modal.

\section{Pemusnahan}

Pemusnahan pada Pemerintah Kabupaten Gorontalo dilakukan terhadap barang yang rusak berat dan sudah tidak memiliki masa manfaat lagi, yang jika diperhitungkan biaya pemeliharaannya akan jauh lebih tinggi. Pengguna Barang terlebih dahulu harus mengajukan usulan pemusnahan kepada Pengelola Barang, setelah disetujui dan Surat Keputusan diterbitkan maka pemusnahan dapat dilakukan dengan cara dibakar dan terlebih dahulu mengambil foto atas barang-barang tersebut sebagai bukti dokumentasi sudah dilaksanakannya pemusnahan pada SKPD yang dimaksud. Berdasarkan hasil wawancara dapat disimpulkan bahwa pelaksanaan proses pemusnahan pada Pemerintah Kabupaten Gorontalo sudah dilaksanakan sesuai dengan peraturan. Dimana dalam Peraturan Menteri Dalam Negeri Nomor 19 Tahun 2016 dijelaskan bahwa pemusnahan Barang Milik Darah dilaksanakan oleh Pengguna Barang setelah mendapatkan persetujuan dari Pengelola Barang dengan pertimbangan bahwa barang tersebut sudah tidak dapat digunakan, tidak dapat dimanfaatkan, dan/atau tidak dapat dipindahtangankan atau terdapat alasan lain sesuai dengan ketentuan peraturan perundang-undangan. Pemusnahan Barang Milik Daerah dilakukan oleh SKPD dan proses pembuatan SK pemusnahan dibuat oleh Bidang Aset yang kemudian dilaporkan kepada Pengelelola Barang. Cara-cara pemusnahan Barang Milik Daerah sama seperti yang diungkapkan dalam hasil penelitian Tukunang (2016) bahwa pemusnahan dilakukan dengan cara dibakar, ditanam ke tanah atau ditenggelamkan ke laut.

\section{Penghapusan}

Penghapusan pada Pemerintah Kabupaten Gorontalo dilakukan oleh Pengguna Barang dengan terlebih dahulu mengajukan usulan penghapusan kepada Pengelola Barang. Selanjutnya Bidang Aset akan melakukan kajian dengan melakukan penelitian atau pengecekan fisik terhadap barang yang akan dihapus, apakah benar barang-barang tersebut sudah rusak dan sudah tidak bisa dimanfaatkan lagi. Berdasarkan persetujuan Bupati maka akan diterbitkan Surat Keputusan penghapusan. Berdasarkan hasil wawancara dapat disimpulkan bahwa pelaksanaan proses penghapusan pada Pemerintah Kabupaten Gorontalo sudah dilaksanakan sesuai dengan peraturan. Dimana dalam Peraturan Menteri Dalam Negeri Nomor 19 Tahun 2016 dijelaskan bahwa penghapusan dari Daftar Barang Milik Daerah dilakukan karena : a) pemindahtanganan atas Barang Milik Daerah; b) putusan pengadilan yang telah berkekuatan hukum tetap dan sudah tidak ada upaya hukum lainnya; c) menjalankan ketentuan undang-undang; d) pemusnahan; atau e) sebab lain.

Namun hasil penelitian menunjukkan bahwa pelaksanaan proses penghapusan pada Pemerintah Kabupaten Gorontalo belum sepenuhnya dilaksanakan secara optimal karena masih terkendala dengan para Pengurus Barang yang tidak rutin menyampaikan informasi aset yang rusak dan hilang kepada Bidang Aset. Masalah lainnya lagi yaitu adanya barang-barang yang sudah tidak diketahui lagi keberadaannya, karena jika fisik barang tidak ada maka penghapusan tidak dapat dilakukan. Hal ini akan mempengaruhi penyajian nilai aset pada neraca karena masih ada barang yang dalam kondisi rusak dan hilang masih tercatat di KIB dan neraca. Untuk itu upaya yang dilakukan Pemerintah Kabupaten Gorontalo terkait penghapusan terhadap barang-barang yang sudah tidak diketahui lagi keberadaannya yaitu dengan mengurus Surat Keterangan Kehilangan dari pihak kepolisian untuk dijadikan dasar yang kuat agar barang tersebut dapat dihapus. Hal ini didukung oleh Darise (2009) yang menyebutkan bahwa penghapusan merupakan tindakan menghapus aset daerah dalam daftar aset dengan menerbitkan surat keputusan dari pejabat yang berwenang untuk membebaskan pengguna dan/atau kuasa pengguna dan/atau pengelola dari tanggung jawab administrasi dan fisik atas barang yang berada dalam penguasaannya.

\section{Penatausahaan}

Penatausahaan pada Pemerintah Kabupaten Gorontalo yang dilakukan oleh Pengguna Barang dengan membuat Kartu Inventaris Barang (KIB), Kartu Inventaris Ruangan (KIR) dan menyusun laporan penatausahaan barang semesteran dan tahunan. Selain itu juga pada tahun 2016, Pemerintah Kabupaten Gorontalo telah melaksanakan sensus Barang Milik Daerah. Berdasarkan hasil wawancara dapat disimpulkan bahwa pelaksanaan proses penatausahaan pada Pemerintah Kabupaten Gorontalo sudah dilaksanakan sesuai dengan peraturan. Dimana dalam Peraturan Menteri Dalam Negeri Nomor 19 Tahun 2016 dijelaskan bahwa Pengguna barang melakukan inventarisasi Barang Milik Daerah 
paling sedikit 1 (satu) kali dalam 5 (lima) tahun. Barang Milik Daerah berupa persediaan dan konstruksi dalam pengerjaan, inventarisasi dilakukan oleh pengguna barang setiap tahun. Kuasa pengguna barang harus menyusun laporan barang kuasa pengguna semesteran dan tahunan sebagai bahan untuk menyusun neraca satuan kerja untuk disampaikan kepada pengguna barang dan pengguna barang menghimpun laporan barang kuasa pengguna semesteran dan tahunan sebagai bahan penyusunan laporan barang pengguna semesteran dan tahunan. Laporan barang pengguna digunakan sebagai bahan untuk menyusun neraca SKPD untuk disampaikan kepada pengelola barang. Menurut Edwards III (1980) dalam Juanda (2011) menyatakan bahwa implementasi akan berjalan efektif apabila ukuran-ukuran dan tujuan-tujuan kebijakan dipahami oleh individu-individu yang bertanggungjawab dalam pencapaian tujuan kebijakan. Oleh karenanya kejelasan ukuran dan tujuan kebijakan dengan demikian perlu dikomunikasikan secara tepat dengan para pelaksana. Penatausahaan yang tertib akan menghasilkan angka-angka yang tepat dan akurat yang berpengaruh pada tersedianya database yang memadai dalam menyusun perencanaan kebutuhan dan penganggaran serta akan menghasilkan laporan aset di neraca dengan angka yang tepat dan akurat.

\section{Pembinaan Pengawasan dan Pengendalian}

Pembinaan Pengawasan dan Pengendalian pada Pemerintah Kabupaten Gorontalo dilakukan oleh Bidang Aset selaku Pembantu Pengelola Barang dengan melaksanakan rekonsiliasi Barang Milik Daerah rutin setiap bulan bersama dengan Pengurus Barang. Selain itu Bidang Aset juga melakukan sosialisasi kepada Pengurus Barang dan lebih menekankan juga akan tanggung jawab dan wewenang Kepala SKPD selaku Pengguna Barang terkait pengelolaan Barang Milik Daerah. Berdasarkan hasil wawancara dapat disimpulkan bahwa pelaksanaan proses pembinaan pengawasan dan pengendalian pada Pemerintah Kabupaten Gorontalo sudah dilaksanakan sesuai dengan peraturan. Dimana dalam Peraturan Menteri Dalam Negeri Nomor 19 Tahun 2016 dijelaskan bahwa pengawasan dan pengendalian Barang Milik Daerah dilakukan oleh pengguna barang melalui pemantauan dan penertiban. Pemantauan dan penertiban dilaksanakan terhadap penggunaan, pemanfaatan, pemindahtanganan, penatausahaan, pengamanan dan pemeliharaan Barang Milik Daerah. Pengawasan dan pengendalian Barang Milik Daerah dilakukan pengelola barang melalui pemantauan dan investigasi.

\section{Pengelolaan Barang Milik Daerah Pada SKPD Yang Menggunakan Pola Pengelolaan Keuangan BLUD}

Pengelolaan Barang Milik Daerah pada SKPD yang menggunakan pola pengelolaan keuangan BLUD pada Pemerintah Kabupaten Gorontalo yaitu sebelumnya terdapat Rumah Sakit MM Dunda yang peraturannya ada dalam Bultek tentang pengelolaan Aset BLUD. Namun pada Tahun 2016, Rumah Sakit MM Dunda yang sebelumnya BLUD sudah ditarik ke Dinas Kesehatan dan menjadi UPTD sendiri. Olehnya saat ini pada Pemerintah Kabupaten Gorontalo sudah tidak ada lagi SKPD yang menggunakan pola pengelolaan keuangan BLUD. Berdasarkan hasil wawancara dapat disimpulkan bahwa pelaksanaan proses pengelolaan Barang Milik Daerah pada SKPD yang menggunakan pola pengelolaan keuangan BLUD pada Pemerintah Kabupaten Gorontalo sudah dilaksanakan sesuai dengan peraturan. Dimana dalam Peraturan Menteri Dalam Negeri Nomor 19 Tahun 2016 dijelaskan bahwa proses pengelolaan Barang Milik Daerah berpedoman pada ketentuan peraturan perundang-undangan mengenai pengelolaan Barang Milik Daerah, kecuali terhadap barang yang dikelola dan/atau dimanfaatkan sepenuhnya untuk menyelenggarakan kegiatan pelayanan umum sesuai dengan tugas dan fungsi Badan Layanan Umum Daerah.

\section{Barang Milik Daerah Berupa Rumah Negara}

Milik Daerah Berupa Rumah Negara pada Pemerintah Kabupaten Gorontalo terdiri dari Rumah Negara Golongan I yang diperuntukkan bagi pemegang jabatan tertentu, seperti Rumah Dinas Bupati dan Sekda. Kemudian Rumah Negara Golongan II itu yang mempunyai hubungan, yang tidak dapat dipisahkan dari suatu SKPD dan hanya disediakan untuk Pegawai Negeri Sipil bersangkutan. Kemudian Rumah Negara Golongan III tidak termasuk pada Golongan I dan Golongan II, dan dapat dijual pada penghuni yang menempatinya. Berdasarkan hasil wawancara dapat disimpulkan bahwa Barang Milik Daerah berupa rumah negara pada Pemerintah Kabupaten Gorontalo secara umum sudah berdasarkan dengan peraturan. Dimana dalam Peraturan Menteri Dalam Negeri Nomor 19 Tahun 2016 dijelaskan bahwa Barang Milik Daerah berupa rumah negara dibagi ke dalam 3 (tiga) golongan yaitu (a) rumah negara golongan I, adalah rumah negara dipergunakan bagi pemegang jabatan tertentu dan 
karena sifat jabatannya harus bertempat tinggal di rumah tersebut serta hak penghuniannya terbatas selama pejabat yang bersangkutan masih memegang jabatan tertentu tersebut; (b) rumah negara golongan II, adalah rumah negara yang mempunyai hubungan yang tidak dapat dipisahkan dari suatu SKPD dan hanya disediakan untuk didiami oleh Pegawai Negeri Sipil pemerintah daerah yang bersangkutan; dan (c) rumah negara golongan III, adalah rumah negara yang tidak termasuk golongan I dan golongan II yang dapat dijual kepada penghuninya. Barang Milik Daerah berupa rumah negara hanya dapat digunakan sebagai tempat tinggal Pejabat atau Pegawai Negeri Sipil Pemerintah Daerah yang bersangkutan yang memiliki Surat Izin Penghunian (SIP).

\section{Ganti Rugi dan Sanksi}

Ganti Rugi dan Sanksi pada Pemerintah Kabupaten Gorontalo sudah dilaksanakan terhadap para Pengguna Barang yang akibat kelalaiannya merugikan daerah. Berdasarkan hasil sensus, ditetapkan kurang lebih 48 (empat puluh delapan) SKPD yang mengikuti proses sidang MPTGR menyangkut Barang Milik Daerah yang sudah tidak diketahui lagi keberadaannya. Berdasarkan hasil wawancara dapat disimpulkan bahwa proses ganti rugi dan sanksi pada Pemerintah Kabupaten Gorontalo secara umum sudah dilaksanakan sesuai dengan peraturan. Dimana dalam Peraturan Menteri Dalam Negeri Nomor 19 Tahun 2016 dijelaskan bahwa tuntutan ganti rugi barang dikenakan terhadap Pegawai Negeri Sipil, Pegawai Perusahaan Daerah dan Pegawai Daerah yang melakukan perbuatan melanggar hukum atau perbuatan melalaikan kewajiban atau melaksanakan kewajiban sebagaimana mestinya sesuai dengan fungsi atau status jabatannya, sehingga karena perbuatannya tersebut mengakibatkan kerugian bagi daerah. Tuntutan ganti rugi barang tidak dapat dilakukan atas dasar sangkaan atau dugaan, akan tetapi harus didasarkan pada kenyataan yang sebenarnya dan dalam pelaksanaannya tidak perlu menunggu Keputusan Pengadilan Negeri.

\section{Penutup}

Kesimpulan penelitian berdasarkan hasil analisis terhadap kondisi yang dijumpai dalam penelitian dimana pengelolaan Barang Milik Daerah pada Pemerintah Kabupaten Gorontalo pada dasarnya telah dilaksanakan sesuai dengan peraturan yang berlaku, namun masih ada hambatan belum adanya regulasi di daerah berupa Perda berdasarkan Peraturan Menteri Dalam Negeri Nomor 19 Tahun 2016, keterbatasan pengetahuan dan pemahaman sumber daya manusia dan kurangnya komitmen pimpinan SKPD dalam mengelola Barang Milik Daerah; Perencanaan kebutuhan barang belum optimal karena masih terdapat kebutuhan barang SKPD yang tidak dapat direalisasikan karena kondisi anggaran yang tidak memungkinkan, selain itu SKPD dalam merencanakan kebutuhan barang sering tidak sesuai kebutuhan atau berlebihan; Pengamanan dan pemeliharaan pelaksanaannya belum optimal karena belum disediakan gudang penyimpanan barang yang representatif, terdapat beberapa bidang tanah milik pemerintah yang belum memiliki sertifikat dan ada juga sertifikat kepemilikan yang masih atas nama Kementerian, kemudian kelalaian para Pengurus Barang yang tidak melakukan pencatatan barang yang dipelihara kedalam Kartu Pemeliharaan; Penghapusan masih terkendala karena adanya barang-barang yang sudah tidak diketahui lagi keberadaannya, karena jika fisik barang tidak ada maka penghapusan tidak dapat dilakukan. Hal ini akan mempengaruhi penyajian nilai aset pada neraca karena masih ada barang yang dalam kondisi rusak dan hilang masih tercatat di KIB dan neraca.

Saran yang dapat diberikan dari penelitian ini : 1) Pemerintah Kabupaten Gorontalo perlu segera menetapkan Perda pengelolaan Barang Milik Daerah yang berpedoman pada Peraturan Menteri Dalam Negeri Nomor 19 Tahun 2016 sehingga pelaksanaan pengelolaan Barang Milik Daerah di Pemerintah Kabupaten Gorontalo mendapat kepastian hukum; 2) Pemerintah Kabupaten Gorontalo perlu segera membuat dan menetapkan Standar Operasional Prosedur (SOP) tentang pengelolaan Barang Milik Daerah untuk memudahkan pemahaman proses pengelolaan Barang Milik Daerah, memudahkan pemberian tugas dan tanggungjawab, serta memudahkan dalam kontrol ketepatan waktu pelaporan dan monitoring; 3) Pemerintah Kabupaten Gorontalo perlu mengadakan sosialisasi, bimbingan dan pelatihan teknis bagi Kepala SKPD selaku Pengguna Barang dan Pengurus Barang untuk meningkatkan kompetensi, komitmen, pemahaman dan kapasitas mereka dalam melakukan pengelolaan Barang Milik Daerah; 4) Pemerintah Kebupaten Gorontalo perlu melibatkan Bidang Aset dalam hal proses perencanaan kebutuhan dan penganggaran di SKPD untuk dapat memberikan pertimbangan dan menghindari proses perencanaan kebutuhan barang yang berlebihan. 5) Pemerintah Kabupaten Gorontalo perlu mewajibkan kepada setiap Pengguna Barang untuk menyediakan gudang penyimpanan barang yang representatif di setiap SKPD-SKPD sebagai kontrol terhadap pengamanan 
Barang Milik Daerah. 6) Pemerintah Kabupaten Gorontalo perlu melakukan penelusuran barang yang sudah tidak diketahui lagi keberadaannya namun masih tercatat dalam nilai aset. Ini dilakukan dengan maksud agar dalam penghapusan suatu barang nantinya tidak akan mengalami kesulitan.

\section{Daftar Pustaka}

Badan Pemeriksa Keuangan Republik Indonesia. 2015. Laporan Hasil Pemeriksaan atas Sistem Pengendalian Internal Pemerintah Kabupaten Gorontalo. 2014. Laporan Hasil Pemeriksaan atas Sistem Pengendalian Internal Pemerintah Kabupaten Gorontalo. . 2013. Laporan Hasil Pemeriksaan atas Sistem Pengendalian Internal Pemerintah Kabupaten Gorontalo. . 2012. Laporan Hasil Pemeriksaan atas Sistem Pengendalian Internal Pemerintah Kabupaten Gorontalo. . 2011. Laporan Hasil Pemeriksaan atas Sistem Pengendalian Internal Pemerintah Kabupaten Gorontalo.

Darise, Nurlan. 2009. Pengelolaan Keuangan Daerah. Jakarta: PT Indeks.

Hasfi, Nyemas. 2013. Pengelolaan Barang Milik Daerah (Suatu Studi Pada Dinas Pendapatan, Pengelolaan Keuangan dan Aset Kabupaten Sintang). Magister Ilmu Sosial Pascasarjana Universitas Tanjungpura Pontianak. Jurnal Tesis PMIS UNTAN PSIAN Vol.1, No.0001, Hal.117.

Juanda, 2011. Implementasi Good Governance Dalam Proses Transfer Aset Pemerintah Daerah Kota Metro. Magister Ilmu Pemerintahan Pascasarjana Universitas Lampung. Tesis.

Mardiasmo. 2009. Akuntansi Sektor Publik. Yogyakarta: Andi.

Republik Indonesia. 2010. Peraturan Presiden Nomor 54 Tahun 2010 tentang Pengadaan Barang dan Jasa. Sekretariat Negara RI.

Republik Indonesia. 2016. Peraturan Menteri Dalam Negeri Nomor 19 Tahun 2016 tentang Pedoman Teknis Pengelolaan Barang Milik Daerah. Sekretariat Negara RI.

Sholeh, C., \& Rochmansjah, H. 2010. Pengelolaan Keuangan dan Aset Daerah Sebuah Pendekatan Struktural Menuju Tata Kelola Pemerintahan Yang Baik. Bandung: Fokusmedia.

Subagya. 1996. Manajemen Logistik. Jakarta: PT. Toko Gunung Agung.

Simamora, Rudianto. 2013. Faktor-Faktor Yang Mempengaruhi Pengelolaan Aset Pasca Pemekaran Wilayah dan Pengaruhnya Terhadap Kualitas Laporan Keuangan Pemerintah di Kabupaten Tapanuli Selatan. Magister Sains Akuntansi Pascasarjana Universitas Gadjah Mada Yogyakarta. Jurnal Ekonomi dan Bisnis ISSN:1693-0908, Vol.13, No.2, Hal.29-43.

Sumampow, Nancy. 2015. Implementasi Kebijakan Pengelolaan Barang Milik Daerah Pada Dinas Pendidikan, Pemuda dan Olahraga Kabupaten Sigi. Magister Administrasi Publik Pascasarjana Universitas Tadulako Palu. Jurnal Katalogis ISSN: 2302-2019. Vol.3, No.2, Hal.160-172.

Suwanda, Dadang. 2013. Strategi Mendapatkan Opini WTP Laporan Keuangan Pemda. Jakarta: PPM.

Takunang, Stanly. 2016. Manajemen Aset Daerah Pada Dinas Pendapatan Pengelolaan Keuangan dan Aset Daerah Kabupaten Kepulauan Siau, Tagulandang, Biaro. Magister Manajemen Pascasarjana Universitas Sam Ratulangi Manado. Jurnal EMBA ISSN:2303-1174, Vol.4, No.2, Hal.236-253.

Taylor, S.E. 2006. Health Psychology. (6th. Ed), Singapore: Mc. Graw Hill Book Company.

Yin, Robert K. 2014. Studi Kasus: Desain \& Metode. 2014. Jakarta: PT. Raja Grafindo Persada. 